\title{
Review
}

\section{Reactive Oxygen Species: Stuck in the Middle of Neurodegeneration}

\author{
David A. Patten ${ }^{1}$, Marc Germain ${ }^{1}$, Melissa A. Kelly and Ruth S. Slack* \\ Department of Cellular and Molecular Medicine, University of Ottawa, Ottawa, ON, Canada
}

Accepted 5 April 2010

\begin{abstract}
Neuronal cell loss associated with neurodegeneration has recently been linked to mitochondrial dysfunction. Electron transport chain defects and reactive oxygen species (ROS) production are emerging as important players in the etiology of neurodegenerative diseases. Proper management of ROS and disposal of damaged cellular components are vital to the survival and function of neurons. Proteins involved in these pathways are often mutated in neurodegenerative diseases such as Alzheimer's disease, Parkinson's disease, amyotrophic lateral sclerosis, and Huntington's disease. In this review, we will discuss the roles of ROS in normal physiology, how changes in ROS production affect neuronal survival in neurodegenerative diseases, and the recent advances in mitochondrial antioxidants as potential therapeutics.
\end{abstract}

Keywords: Apoptosis, autophagy, mitochondria, neurodegeneration, reactive oxygen species

\section{INTRODUCTION}

Neurodegenerative diseases are characterized by the progressive loss of specific neuronal populations. Accumulation of protein aggregates occurs in the affected neuronal populations and has been suggested to be at the origin of their demise, at least under some circumstances. Accumulating evidence suggests, however, that mitochondrial dysfunction also plays an important role in the etiology of neurodegenerative diseases. The management of mitochondrial reactive oxygen species (ROS) and the damage they cause is emerging as a major contributor to neuronal loss in Alzheimer's disease (AD), Parkinson's disease (PD), amyotrophic lateral sclerosis (ALS), and Huntington's disease (HD). In this review, we will discuss the roles of ROS in normal physiology as well as the causes and consequences

\footnotetext{
${ }^{1}$ These authors contributed equally to this work.

* Correspondence to: Ruth S. Slack, Ph.D., Ottawa Health Research Institute, University of Ottawa, 451 Smyth Road, Ottawa, ON, Canada K1H 8M5. Tel.: +1 613562 5800, ext. 8458; Fax: +1 613 562 5403; E-mail: rslack@uottawa.ca.
}

of mitochondrial-generated ROS in neurodegenerative diseases.

\section{REACTIVE OXYGEN SPECIES}

ROS are a group of small oxygen-containing free radicals that are extremely reactive due to their unpaired valence electrons. ROS are generally formed by the primary ROS superoxide $\left(\mathrm{O}_{2}^{-}\right)$, which is chiefly converted to hydrogen peroxide $\left(\mathrm{H}_{2} \mathrm{O}_{2}\right)$ by superoxide dismutases (SOD) but may also be protonated to form hydroperoxyl radicals $\left(\mathrm{HO}_{2}^{-}\right) . \mathrm{H}_{2} \mathrm{O}_{2}$ can be transformed into a number of other ROS including hydroxyl radicals $(\mathrm{OH})$, hydroxyl anions (HO-), singlet oxygen $\left({ }^{1} \mathrm{O}_{2}\right)$ and hypochlorite $\left(\mathrm{ClO}^{-}\right)$. There are many generators of cellular ROS including the mitochondrion, nicotinamide adenine dinucleotide phosphate (NADPH) oxidase (reviewed in [1]), xanthine oxidase [2], and uncoupled endothelial nitric oxide synthase (eNOS) [3]. In the majority of cell types, the mitochondrion is the major source of ROS. Superoxide production, due to inefficiencies in oxidative phosphorylation, accounts for 
up to $2 \%$ of the total oxygen consumed by mitochondria [4]. Mitochondrial-generated ROS (mtROS) are mainly produced at complex I and complex III of the electron transport chain, although a total of nine sites have been identified [5]. Complex I produces superoxide solely in the matrix while complex III generates superoxide in both the matrix and the intermembrane space [6].

One cannot discuss ROS without discussing its clearance. Cells possess a number of antioxidant defenses chiefly to protect the cell from oxidative stress, but are also involved in other functions including cellular signaling. As a charged molecule, superoxide is generally membrane impermeable and is a particularly damaging molecule. It is, however, rapidly converted to $\mathrm{H}_{2} \mathrm{O}_{2}$ by superoxide dismutases: copper/zinc superoxide dismutase (SOD1) in the cytoplasm and mitochondrial intermembrane space; and by manganese superoxide dismutase (SOD2) in the mitochondrial matrix [7]. The importance of superoxide detoxification is highlighted by the fact that SOD2 knockout mice live only weeks [8]. $\mathrm{H}_{2} \mathrm{O}_{2}$, however, is membrane permeable and is likely the main signaling molecule in ROS-mediated pathways. $\mathrm{H}_{2} \mathrm{O}_{2}$ is detoxified in cells by glutathione peroxidase (GPx), and in some cases by catalase, to form water [7]. Prolonged high levels of ROS that surpass the cell's antioxidant capacity result in oxidative stress.

\section{ROS AS SIGNALING MOLECULES}

Although high ROS concentrations are damaging to lipids, proteins, and DNA, there is a large body of evidence demonstrating that low and intermediary levels of ROS are physiologically important (reviewed in [9] and [10]). NADPH oxidase-derived ROS (noxROS), for instance, have been well characterized in the cardiovascular field for their role in cell signaling. NADPH oxidases are a group of enzyme complexes highly expressed in phagocytes and cardiovascular tissue, which catalyze the reduction of oxygen to form superoxide. In phagocytes, NADPH oxidase produces large bursts of ROS, killing foreign organisms as part of the immune defense system [11]. In cardiovascular tissue, however, NADPH oxidase produces relatively less ROS at a slow and sustained rate, serving as intracellular signaling molecules [12]. NADPH activity is regulated by growth factors, vasoactive agents, and cytokines: the signaling of which results in the assembly and activation of the complex. Increased noxROS result in the activation of key survival pathways, notably mitogen-activated pro- tein kinase (MAPK) pathways and the phosphoinositide 3-kinase (PI3K)/Akt pathway [10], presumably through the oxidation of key cysteine residues. Depending on the stimulus, activation of these pathways may induce cell growth, apoptosis, proliferation, migration, or smooth muscle contraction [13]. Increased noxROS is involved in the development of cardiovascular disease through activation of these pro-survival pathways. For example, noxROS play a pivotal role in vascular remodeling implicated in angiotensin II (Ang II)-dependent hypertension (reviewed in [14]).

In addition to the activation of the aforementioned signaling pathways, ROS are also involved in activation of transcription factors that regulate cellular responses to ROS. One of the first responses to increased ROS is the upregulation of antioxidant defenses. Nrf2 is a major transcription factor activated by oxidative stress regulating expression of several important antioxidant proteins such as superoxide dismutases, peroxiredoxins, glutathione peroxidases, and heme oxygenases ([15] and reviewed in [16]). Nrf2 is normally kept inactive by interacting with Keap1 in the cytosol where it is targeted for ubiquitin-dependent proteasomal degradation. The interaction between Keap1 and Nrf2 is disrupted with increased ROS production, allowing Nrf2 to translocate to the nucleus and activate transcription [17]. Interestingly, the PD-related gene DJ-1 has been proposed to promote the dissociation of Nrf2 from Keap1, thereby increasing its activity [18].

While Nrf2 plays an important role in regulating antioxidant defenses in response to elevated ROS, other ROS-activated transcription factors, such as hypoxiainducible factors (HIFs), control several aspects of cellular functions. HIFs are the master transcription factors responsible for the adaptation of cells to low oxygen (hypoxia). HIFs maintain oxygen and energy homeostasis by regulating genes involved in metabolism, proliferation, erythropoiesis, angiogenesis, and cell survival [19]. Active HIF is a heterodimer regulated primarily though degradation or stabilization of its oxygen sensitive $\alpha$ subunit, while its $\beta$ subunit is constitutively expressed. Under normal oxygen conditions, HIF $\alpha$ is rapidly degraded by the proteasome; however, during hypoxic conditions HIF $\alpha$ is stabilized, dimerizes with HIF $\beta$ and activates transcription of its target genes. In addition to oxygen levels, HIF $\alpha$ is also regulated through mtROS [20-22]. Inhibition of mtROS through pharmacological and genetic inhibition of complex III, and through antioxidant treatments, indeed lead to increased HIF $\alpha$ stability [20-22]. mtROS stabilize HIF $\alpha$ by inhibiting HIF prolyl-hydroxylases (PHDs), key en- 
zymes responsible for HIF degradation. PHD inhibition by ROS probably occurs via the Fenton reaction which oxidizes $\mathrm{Fe}^{2+}$ to $\mathrm{Fe}^{3+}$, where $\mathrm{Fe}^{2+}$ is an essential co-factor [23]. Interestingly, recent evidence demonstrates that HIF activation plays a protective role in neurodegenerative diseases (reviewed in [24]). For instance, the PHD inhibitor 3,4-dihydroxybenzoate has recently been shown to protect neurons from the MPTP model of $\mathrm{PD}$ both in vitro and in vivo [25].

Nuclear factor-kappa B (NF- $\kappa \mathrm{B})$ is a second prosurvival transcription factor activated by ROS that regulates several important cellular defense mechanisms. NF- $\kappa \mathrm{B}$ activates target genes involved in cellular survival, growth, differentiation, and inflammation. Normally, NF- $\kappa \mathrm{B}$ is sequestered in the cytoplasm and held inactive by $\mathrm{I} \kappa \mathrm{B}$ (inhibitor of $\kappa \mathrm{B}$ ). Moderate ROS levels lead to phosphorylation and degradation of $\mathrm{I} \kappa \mathrm{B}$ and therefore the activation of NF- $\kappa \mathrm{B}$ [26]. Once activated, NF- $\kappa \mathrm{B}$ plays a pro-survival role through the transcriptional activation of anti-apoptotic proteins, such as XIAP and GADD45 $\beta$ [27], and genes involved in decreasing mtROS, most notably SOD2 [28,29]. In addition, NF- $\kappa \mathrm{B}$ may play a pro-survival role by inhibiting the JNK and caspase cell death pathways [30]. While moderate ROS levels activate NF- $\kappa \mathrm{B}$, high levels inactivate NF- $\kappa$ B through oxidation of cysteine 62 of its p50 subunit, inhibiting its DNA binding [31].

The 553 tumor suppressor represents a different aspect of ROS-activated transcription factors, as it can promote both survival and death. Cellular damage activates p53, leading to the inhibition of cell cycle or initiation of apoptosis [32]. In addition to these classical roles, p53 also presents a pro-survival role in response to increased ROS levels by upregulating several antioxidants, including glutathione peroxidase [33, 34], SOD2 [34], and ALDH4 [35]. p53 also induces the pentose phosphate shunt through regulating TP53-induced glycolysis and apoptosis regulator (TIGAR) [36]. TIGAR inhibits glycolysis and directs glucose to the pentose phosphate pathway producing NADPH, which is required to reduce glutathione (GSH) and thus lower ROS levels [36]. This antioxidant function of p53 is activated during low cellular stress [37], while high stress and ROS concentrations results in p53-mediated apoptosis through activation of several pro-apoptotic genes such as BH3-only proteins [38] and a series of p53-induced genes (PIGs) [39]. Although the exact mechanism by which p53 senses ROS and responds via either pro-apoptotic or anti-apoptotic functions remains relatively unknown, these differing functions possibly depend on p53 levels, posttranslational modification, and cellular localization [40].
Taken together these studies suggest that while high ROS levels are damaging, low levels play an integral role in pro-survival pathways through both the activation of key signaling pathways and the activation of transcription factors (Fig. 1).

\section{ROS IN NEURODEGENERATIVE DISEASES}

Excessively high levels of ROS beyond the clearance capacity of the cell cause oxidative stress, mitochondrial dysfunction, cellular damage, and, in numerous cases, cell death. A range of data suggests that oxidative stress is at the center of various neurodegenerative diseases. Among these diseases, evidence of increased ROS has been reported in ALS [41], HD [42], PD [43, $44]$, and AD $[45,46]$. The most direct example is in cases of familial ALS (FALS) in which the antioxidant enzyme SOD1 is mutated [47,48]. Dysfunctional SOD1 causes an increase in oxidative stress, as shown in several animal models of ALS in which mutant human or mouse SOD1 are expressed. The toxicity of SOD1 mutants amounts to more than a disrupted enzymatic function, however, as the mutant protein forms toxic aggregates within mitochondria [49,50], impairing respiration and promoting mitochondrial dysfunction [51]. Increased ROS in FALS is therefore likely the result of a combination of loss of antioxidant function and accumulation of toxic SOD1 aggregates.

ROS generation in neurodegenerative diseases go beyond such a direct effect on antioxidant function, although mitochondrial damage is a recurrent theme. For example, decreased mitochondrial respiration [52], as well as increased ROS and oxidative DNA damage have been reported in HD transgenic mice and in the parietal cortex of human HD brains [42,53,54], while antioxidant treatment with Coenzyme $\mathrm{Q}_{10}$ promoted moderate improvement in disease progression and extended survival [55]. However, the best-characterized neurodegenerative disease where mitochondrial dysfunction is linked to ROS production is PD.

The first evidence for a role of ROS in PD came from the observation that human PD brains show signs of mitochondrial dysfunction and oxidative damage in degenerating areas including the substantia nigra $[43,44]$. This was further substantiated by the identification of several PD-related genes that are associated with mitochondrial function, namely the mitochondrial kinase PTEN-induced putative kinase 1 (PINK1), the E3 ligase Parkin, and the oxidative stress sensor DJ-1 [56]. Specifically, mutations in PINK1 cause mitochondrial 


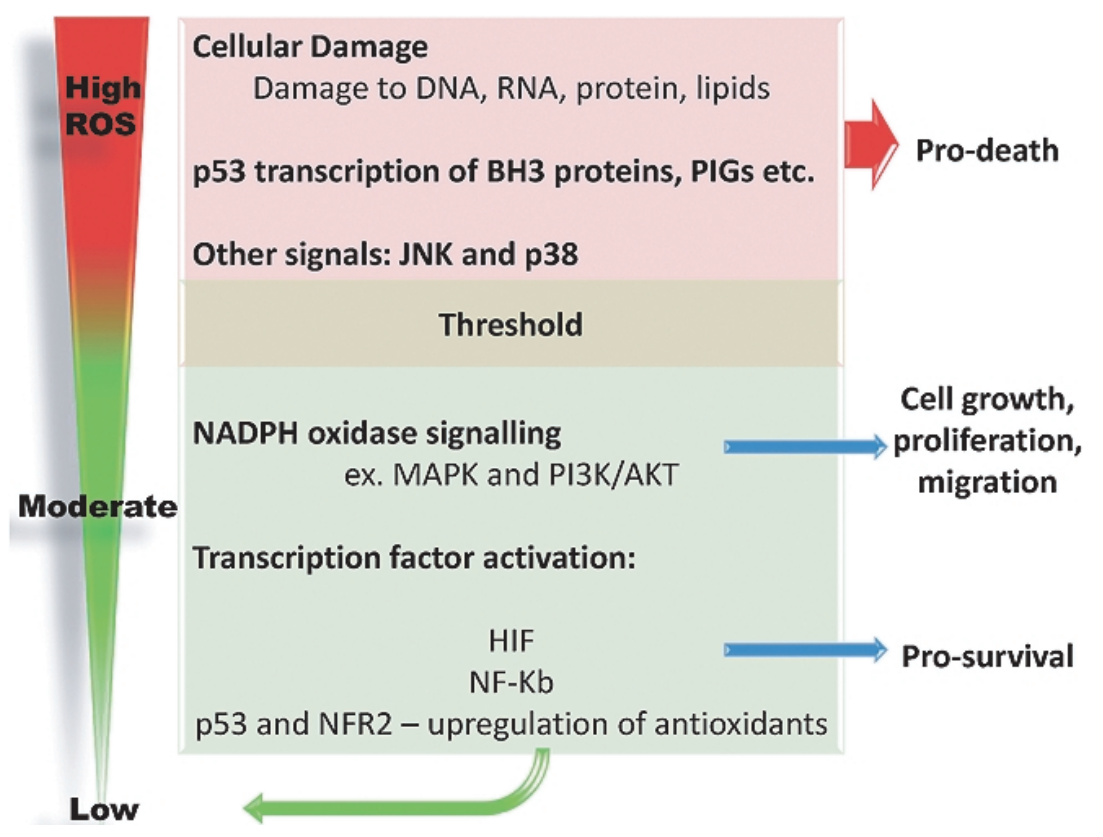

Fig. 1. Model of ROS levels moderating pro-survival and pro-death signaling. Moderate increases in ROS lead to activation of various cell signaling events that are generally pro-survival pathways. Moreover, activation of p53 and NRF2 are important to return the cell to a lower oxidative state by regulating the transcription of antioxidants. When ROS production exceeds a specific threshold (cell and stimulus specific), the cellular response shifts to promote cell death.

dysfunction [57], while loss of Parkin in mouse models has been shown to result in oxidative stress and mitochondrial dysfunction [58]. Recently, loss of DJ-1 in mouse embryonic fibroblasts (MEFs) has been associated with decreased respiration, increased mtROS, and reduced mitochondrial membrane potential [59]. Interestingly, PINK1, Parkin, and DJ-1 potentially interact in a complex to stimulate proteasomal degradation of proteins likely to aggregate, effectively preventing the accumulation of these neurotoxins [60]. The beneficial role of PINK1 and Parkin may also be involved in clearance of damaged mitochondria resulting in additional reductions in ROS (discussed below).

ROS production has also been linked to another key feature of neurodegenerative diseases, namely the accumulation of protein aggregates, although this relationship is complex. For example, expression of PD mutant $\alpha$-synuclein (a component of Lewy bodies in PD) in mice and neurons is toxic, induces mitochondrial dysfunction, and increases ROS and cell death [6163]. A second example where accumulation of protein aggregates has been linked to mitochondrial dysfunction and ROS production is in AD. The presence of amyloid- $\beta(\mathrm{A} \beta)$ plaques is a characteristic feature of $\mathrm{AD}$ and its accumulation has been linked to oxidative stress, mitochondrial dysfunction, energy failure, synaptic dysfunction, and ultimately neuronal loss [6466]. Indeed, AD brains show signs of increased ROS including nuclear DNA and mitochondrial DNA (mtDNA) damage $[45,46]$, while mitochondrial accumulation of $\mathrm{A} \beta$ reduces oxygen consumption, and decreases mitochondrial electron transport chain activity [64,67]. One other way in which $\mathrm{A} \beta$ may affect ROS production is through its effect on mitochondrial dynamics. Mitochondria exist as a highly dynamic network that constantly divide and fuse. Recent evidence suggests that $\mathrm{A} \beta$ disrupts this process, leading to mitochondrial fragmentation and increased ROS production [68-70].

The causative role of $\mathrm{A} \beta$ in $\mathrm{AD}$, however, remains debated, and it is clear that other aspects of the disease, such as hyperphosphorylation and accumulation of tau, also play an important role in its progression. In that respect, it is interesting to note that while protein aggregates can promote ROS production and mitochondrial dysfunction, ROS may also cause the accumulation of these neurotoxic aggregates, including $\mathrm{A} \beta$ [71] and $\alpha$-synuclein $[57,72,73]$. This, along with the observation that the increase in ROS production precedes the pathological appearance of A $\beta$ plaques [64,65], suggests that mitochondria dysfunction can be an early event that precedes protein aggregation. It should also be kept in mind, however, that mitochondrial dysfunc- 
tion might be secondary to alterations in other pathways that can affect both mitochondrial function and accumulation of toxic proteins. For example, deregulated calcium homeostasis in $\mathrm{AD}$ may also play a role in ROS generation, $\mathrm{A} \beta$ aggregation, and damage to mitochondria [74-76] with $\mathrm{A} \beta$ oligomers further promoting intracellular calcium entry in a deleterious positive feedback loop [77].

Oxidative stress is thus emerging as a common theme in neurodegeneration (Fig. 2), with decreased mitochondrial antioxidants, increased protein aggregation, and increased mitochondrial dysfunction all promoting increased ROS generation. While several pathways (described above) are activated to control ROS production, dysfunctional mitochondria need to be removed to prevent further damage. Recent work has highlighted a role for autophagy in clearance of damaged mitochondria.

\section{AUTOPHAGY AND APOPTOSIS}

Macroautophagy (hereafter referred to as autophagy) is a conserved catabolic process allowing for recycling of nutrients during starvation. A basal level of autophagy is required to degrade damaged proteins and organelles. Autophagy is characterized by formation of double-membrane vesicles which deliver the cellular components to be recycled to lysosomes where they are degraded. Autophagosome formation is dependent on a series of conserved autophagy-related (ATG) genes (reviewed in [78]).

A role for autophagy in neurodegenerative diseases was first suggested by the phenotype of the ATG5 and ATG7 (two essential ATG genes) conditional knockouts in the central nervous system, where both models lead to an accumulation of ubiquitin-positive aggregates, neuronal loss, and death of the animals within several weeks of birth $[79,80]$. More recently, damaged mitochondria have been shown to be specifically removed by autophagy (mitophagy) in a process requiring PINK1 and Parkin, two aforementioned PDrelated genes [81-84]. PINK1 is a labile mitochondrial outer membrane kinase that is stabilized on mitochondria that have lost their membrane potential $[81,83$, 84]. Following this increase in protein levels, PINK1 recruits the ubiquitin E3-ligase Parkin to the damaged mitochondria in a manner dependent on PINK1 kinase activation $[81,83,84]$. Once on the mitochondrial outer membrane, Parkin ubiquitinates substrates including VDAC1, leading to the recruitment of p62/SQSTM, a ubiquitin binding protein that targets ubiquitinated substrates to autophagosomes for autophagy-dependent degradation [81]. PD-related mutations in either PINK1 or Parkin lead to the accumulation of damaged organelles, increases in dysfunctional mitochondria, and elevated ROS, further damaging the cell.

Failure to properly control ROS production and remove damaged organelles via mitophagy results in accumulation of damage and cell death. At least two types of cell death have been associated with ROS production: apoptosis and necrosis. High levels of ROS, associated with severe cellular damage can lead to necrotic cell death in a process that causes disruption of the cell membrane, causing further inflammation and tissue damage [85]. On the other hand, apoptosis is a tightly controlled process leading to complete removal of the damaged cells without eliciting an inflammatory response [85]. Apoptosis is regulated by a family of related proteins, BCL-2 homologues, that converge on mitochondria to regulate its outer membrane permeability and the release of several pro-apoptotic factors from the intermembrane space (reviewed in [86, 87]). Among these, Apoptosis Inducing Factor (AIF) and Endonuclease G (EndoG) translocate to the nucleus where they cause caspase-independent DNA degradation and cell death [88]. However, the major pathway activated in apoptotic cells relies on the release of cytochrome c [86,87]. Once in the cytosol, cytochrome $\mathrm{c}$ activates formation of the apoptosome, a protein complex comprised of cytochrome c, APAF-1 and caspase-9. The apoptosome activates effector caspases, the apoptotic proteases responsible for morphological changes leading to the dismantling of the cellular component. Cytochrome c release is dependent upon activation of two pro-apoptotic BCL-2 homologues, BAX and BAK [86,87]. Anti-apoptotic BCL-2 homologues (BCL-2, MCL-1, BCL-XL, and A1) inhibit apoptosis by blocking BAX/BAK function in healthy cells. The key molecules for BAX/BAK activation are the BH3-only proteins, a third class of BCL-2 homologues. BH3-only proteins induce BAX/BAK activation either through direct interaction (the so-called activator BH3 BID and BIM) or indirectly by inhibiting anti-apoptotic BCL-2 homologues [86,87]. While the exact contribution of each pathway is still debated, it is clear that BH3-only proteins are the upstream activators of cytochrome c release and apoptosis [86,87]. Activation of BH3-only proteins occurs through several mechanisms [86,87]. For example, BID activation is dependent on its cleavage by caspase- 8 while BAD is regulated by phosphorylation. However, the main regulatory 


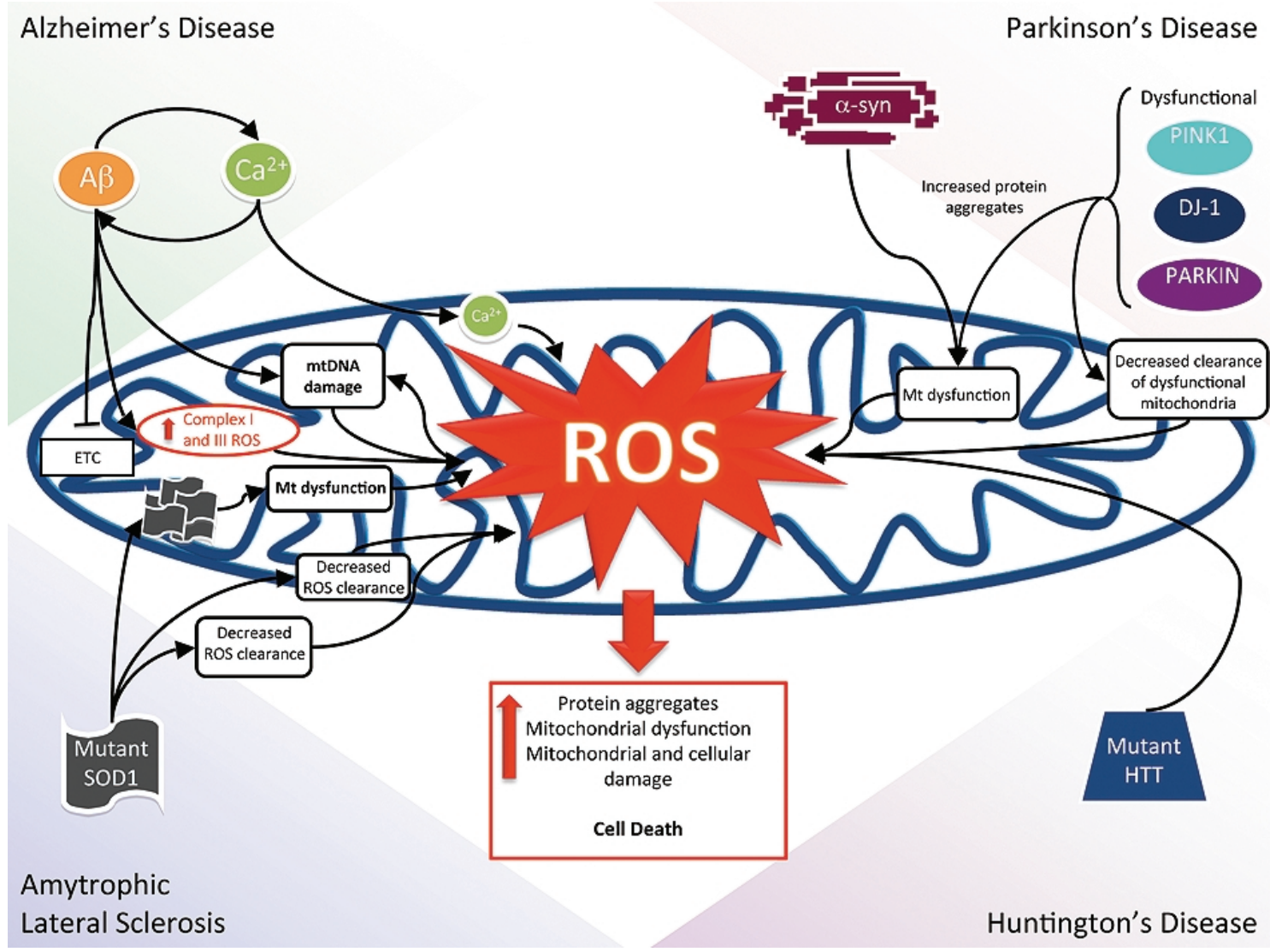

Fig. 2. Schematic of factors affecting mtROS in neurodegenerative diseases. Multiple pathways in neurodegenerative disease converge on the mitochondria to induce the production of mtROS. In the case of $\mathrm{AD}, \mathrm{A} \beta$ accumulation is toxic to mitochondrial respiration and increases mtDNA damage and mtROS. In addition, deregulated $\mathrm{Ca}^{2+}$ levels are also detrimental to proper mitochondrial function. These two components are not mutually exclusive in that $\mathrm{A} \beta$ accumulation can deregulate $\mathrm{Ca}^{2+}$ levels and vice versa. Mutations in PD-related genes cause protein aggregation leading to mitochondrial dysfunction and oxidative stress. In addition, dysfunctional mitochondria are not appropriately disposed of by mitophagy, further increasing mtROS production. Aberrant levels of the mutant form of the protein huntingtin causes ROS generation in HD. Finally, mutations in SOD1 in FALS hinder ROS clearance and create toxic mitochondrial aggregates. Generation of ROS may in turn lead to further protein aggregation, mitochondrial dysfunction, cell damage, and cell death.

mechanism for several BH3-only proteins is transcriptional regulation. Following several types of cellular injury, including increased ROS, p53 is stabilized and activates expression of at least three $\mathrm{BH} 3$-only proteins, namely Noxa, Puma, and human BIK [38,89], providing a link between increased ROS production and induction of apoptosis. As p53 activation also promotes survival under some circumstances, other factors such as JNK and p38 are likely to participate in activation of $\mathrm{BH} 3$-only proteins following an increase in ROS. For example, JNK is activated by ROS and phosphorylates several apoptosis-related substrates such as MCL1 and the BH3-only protein BIM [90,91]. In the case of MCL-1, this results in its proteasome-dependent degradation [91] while JNK-dependent phosphorylation of BIM increases its pro-apoptotic activity [90].
Interestingly, several links exist between autophagy and apoptosis. For example, anti-apoptotic BCL-2 homologues can regulate the activation of autophagy through inhibition of Beclin-1, a protein required for the initiation of autophagosome formation [92,93]. In addition, JNK is activated by starvation (a classical autophagy inducer) and promotes autophagy through several mechanisms including inhibition of BCL-2 [94] and induction of p62 [95]. As discussed above, autophagy is a protective mechanism that promotes disposal of damaged cellular components. However, sustained or excessive autophagy can also lead to autophagic (type II) cell death [96]. Keeping a proper balance between the different aspects of ROS production and clearance (including ROS signaling and autophagic removal of damaged organelles) is therefore key to 
maintaining survival of cells with high metabolic rates and long lifespan such as neurons.

\section{MITOCHONDRIAL ANTIOXIDANTS}

Since ROS and oxidative damage underlie a large number of human diseases, attempts have been made in administering large doses of antioxidants to patients. Unfortunately, these treatments have been largely unsuccessful, likely due to their limited cellular and mitochondrial uptake. In an attempt to increase uptake and efficacy, a large effort has commenced to develop mitochondrial targeted antioxidants (reviewed in [97]). Mitochondria-targeted ubiquinol (MitoQ), for example, was shown to prevent cell death caused by endogenous oxidative stress hundreds of times more potently than its untargeted homologue [98]. Of note here, MitoQ also inhibited HIF accumulation in hypoxia [22]. Furthermore, MitoQ gave promising results in the cardiovascular field where MitoQ treatment reduced cardiac hypertrophy and improved endothelial function of stroke-prone spontaneously hypertensive rats [99]. MitoQ entered into Phase II clinical trials for the treatment of both PD and hepatitis C in 2008. Results, however, remain to be presented.

Another example of a promising mitochondrial targeted antioxidant is SkQ1 [100], shown to reduce $\mathrm{H}_{2} \mathrm{O}_{2}$-induced apoptosis in human fibroblasts and HeLa cells [101]. SkQ1 has produced some extraordinary in vivo results including restoring vision to blind animals with retinopathy, decreasing lymphomas in $\mathrm{p} 53^{-/}$mice, and prolonging the lifespan of fungi, crustaceans, flies, and mice [101]. Further research will be needed to investigate whether or not SkQ1 can prevent neuronal cell death and if it could be used as a potential treatment in neurodegenerative diseases.

Szeto-Schiller (SS) peptides represent a second class of mitochondrial antioxidants that offer the advantage of localizing to mitochondria irrespective of mitochondrial membrane potential, which may improve their therapeutic potential [102]. SS peptides concentrate 1000 -fold to mitochondria, reduce ROS in neuronal cells, and protect cells against neuronal cell death by tert-butyl hydroperoxide [103]. Additionally, in both mouse and human islet cells where mitochondrial dysfunction is at the center of cell death, SS peptides prevented mitochondrial depolarization and apoptosis [104]. In vivo, SS peptides are protective in a mouse model of ALS, increasing survival and motor performance, and decreasing cell loss [105]. SS peptides al- so protect dopaminergic neurons against 1-methyl-4phenyl-1,2,3,6-tetrahydropyridine (MPTP) neurotoxicity both in cell cultures and in the PD animal model [106].

The links between neurodegenerative diseases and ROS presented above, along with the results obtained using these new antioxidants, present compelling in vitro and in vivo evidence that ROS underlie neuronal death. These new mitochondrial ROS scavengers therefore represent a promising novel therapeutic approach to the treatment of these diseases.

\section{CONCLUSION}

As more efficient and better-tolerated mitochondrial antioxidants become available, there are a number of important matters to consider. First of all, mitochondrial antioxidant treatments may inhibit ROS-dependent apoptosis, but not the underlying mitochondrial defects and may therefore result in other non-ROS mediated cell death pathways. Secondly, since mtROS are involved in beneficial cell signaling, including some prosurvival pathways previously discussed, it will be important to ensure that these pathways are not blocked by these treatments. Perhaps moderate doses of mitochondrial antioxidants will be most efficient since the beneficial pro-survival pathways will remain relatively unaltered. And finally, since oxygen sensing through HIF requires mtROS [20], it would be interesting and important to investigate whether these treatments make mammals more susceptible to cell death following ischemic injury.

Regardless, mitochondrial antioxidants represent a promising avenue for neurodegenerative disease treatments. Research is still needed, however, to fully delineate the missing steps by which neurodegenerative diseases increase mtROS and how mtROS leads to cell death. These studies will potentially present new pharmacological targets upstream or downstream of ROS generation, allowing to target damaging ROS without interfering with physiological ROS signaling.

\section{ACKNOWLEDGMENTS}

We would like to thank the life side for providing the title. This work was supported by a grant from the Canadian Institutes of Health Research (CIHR) to RSS. DAP holds a Shelby Hayter Pass the Baton Graduate Fellowship from the Parkinson's Research Consortium. 
MG holds a Parkinson's Society of Canada Research Fellowship.

Authors' disclosures available online (http://www.jalz.com/disclosures/view.php?id=398).

\section{REFERENCES}

[1] Babior BM (2000) The NADPH oxidase of endothelial cells. IUBMB Life 50, 267-269.

[2] Yokoyama Y, Beckman JS, Beckman TK, Wheat JK, Cash TG, Freeman BA, Parks DA (1990) Circulating xanthine oxidase: potential mediator of ischemic injury. Am J Physiol 258, G564-G570.

[3] Dijkstra G, Moshage H, van Dullemen HM, de Jager-Krikken A, Tiebosch AT, Kleibeuker JH, Jansen PL, van Goor H (1998) Expression of nitric oxide synthases and formation of nitrotyrosine and reactive oxygen species in inflammatory bowel disease. J Pathol 186, 416-421.

[4] Orrenius S (2007) Reactive oxygen species in mitochondriamediated cell death. Drug Metab Rev 39, 443-455.

[5] Andreyev AY, Kushnareva YE, Starkov AA (2005) Mitochondrial metabolism of reactive oxygen species. Biochemistry (Mosc) 70, 200-214.

[6] Muller FL, Liu Y, Van Remmen H (2004) Complex III releases superoxide to both sides of the inner mitochondrial membrane. J Biol Chem 279, 49064-49073.

[7] Zhang DX, Gutterman DD (2007) Mitochondrial reactive oxygen species-mediated signaling in endothelial cells. Am J Physiol Heart Circ Physiol 292, H2023-2031.

[8] Lebovitz RM, Zhang H, Vogel H, Cartwright J, Jr., Dionne L, Lu N, Huang S, Matzuk MM (1996) Neurodegeneration, myocardial injury, and perinatal death in mitochondrial superoxide dismutase-deficient mice. Proc Natl Acad Sci U S A 93, 9782-9787.

[9] Valko M, Leibfritz D, Moncol J, Cronin MT, Mazur M, Telser J (2007) Free radicals and antioxidants in normal physiological functions and human disease. Int J Biochem Cell Biol 39, 44-84.

[10] Groeger G, Quiney C, Cotter TG (2009) Hydrogen peroxide as a cell-survival signaling molecule. Antioxid Redox Signal 11, 2655-2671.

[11] Babior BM (2004) NADPH oxidase. Curr Opin Immunol 16, 42-47.

[12] Griendling KK, Sorescu D, Ushio-Fukai M (2000) NAD(P)H oxidase: role in cardiovascular biology and disease. Circ Res 86, 494-501.

[13] Lassegue B, Griendling KK (2010) NADPH oxidases: functions and pathologies in the vasculature. Arterioscler Thromb Vasc Biol 30, 653-661.

[14] Paravicini TM, Touyz RM (2008) NADPH oxidases, reactive oxygen species, and hypertension: clinical implications and therapeutic possibilities. Diabetes Care 31 Suppl 2, S170S180.

[15] Lee JM, Calkins MJ, Chan K, Kan YW, Johnson JA (2003) Identification of the NF-E2-related factor-2-dependent genes conferring protection against oxidative stress in primary cortical astrocytes using oligonucleotide microarray analysis. $J$ Biol Chem 278, 12029-12038.

[16] de Vries HE, Witte M, Hondius D, Rozemuller AJ, Drukarch B, Hoozemans J, van Horssen J (2008) Nrf2-induced antioxidant protection: a promising target to counteract ROS- mediated damage in neurodegenerative disease? Free Radic Biol Med 45, 1375-1383.

[17] Itoh K, Wakabayashi N, Katoh Y, Ishii T, O'Connor T, Yamamoto M (2003) Keap1 regulates both cytoplasmic-nuclear shuttling and degradation of $\mathrm{Nrf} 2$ in response to electrophiles. Genes Cells 8, 379-391.

[18] Clements CM, McNally RS, Conti BJ, Mak TW, Ting JP (2006) DJ-1, a cancer- and Parkinson's disease-associated protein, stabilizes the antioxidant transcriptional master regulator Nrf2. Proc Natl Acad Sci U S A 103, 15091-15096.

[19] Semenza GL (2003) Targeting HIF-1 for cancer therapy. Nat Rev Cancer 3, 721-732.

[20] Brunelle JK, Bell EL, Quesada NM, Vercauteren K, Tiranti V, Zeviani M, Scarpulla RC, Chandel NS (2005) Oxygen sensing requires mitochondrial ROS but not oxidative phosphorylation. Cell Metab 1, 409-414.

[21] Guzy RD, Hoyos B, Robin E, Chen H, Liu L, Mansfield KD, Simon MC, Hammerling U, Schumacker PT (2005) Mitochondrial complex III is required for hypoxia-induced ROS production and cellular oxygen sensing. Cell Metab 1, 401-408.

[22] Bell EL, Klimova TA, Eisenbart J, Moraes CT, Murphy MP, Budinger GR, Chandel NS (2007) The Qo site of the mitochondrial complex III is required for the transduction of hypoxic signaling via reactive oxygen species production. $J$ Cell Biol 177, 1029-1036.

[23] Bell EL, Klimova T, Chandel NS (2008) Targeting the mitochondria for cancer therapy: regulation of hypoxia-inducible factor by mitochondria. Antioxid Redox Signal 10, 635-640.

[24] Correia SC, Moreira PI (2010) Hypoxia-inducible factor 1: a new hope to counteract neurodegeneration? J Neurochem 112, $1-12$.

[25] Lee DW, Rajagopalan S, Siddiq A, Gwiazda R, Yang L, Beal MF, Ratan RR, Andersen JK (2009) Inhibition of prolyl hydroxylase protects against 1-methyl-4-phenyl-1,2,3,6tetrahydropyridine-induced neurotoxicity: model for the potential involvement of the hypoxia-inducible factor pathway in Parkinson disease. J Biol Chem 284, 29065-29076.

[26] Kamata H, Manabe T, Oka S, Kamata K, Hirata H (2002) Hydrogen peroxide activates IkappaB kinases through phosphorylation of serine residues in the activation loops. FEBS Lett 519, 231-237.

[27] Pahl HL (1999) Activators and target genes of Rel/NFkappaB transcription factors. Oncogene 18, 6853-6866.

[28] Das KC, Lewis-Molock Y, White CW (1995) Activation of NF-kappa B and elevation of MnSOD gene expression by thiol reducing agents in lung adenocarcinoma (A549) cells. Am J Physiol 269, L588-602.

[29] Gloire G, Piette J (2009) Redox regulation of nuclear posttranslational modifications during NF-kappaB activation. Antioxid Redox Signal 11, 2209-2222.

[30] Bubici C, Papa S, Dean K, Franzoso G (2006) Mutual crosstalk between reactive oxygen species and nuclear factorkappa B: molecular basis and biological significance. Oncogene 25, 6731-6748.

[31] Toledano MB, Leonard WJ (1991) Modulation of transcription factor NF-kappa B binding activity by oxidationreduction in vitro. Proc Natl Acad Sci U S A 88, 4328-4332.

[32] Vousden KH, Lane DP (2007) p53 in health and disease. Nat Rev Mol Cell Biol 8, 275-283.

[33] Tan M, Li S, Swaroop M, Guan K, Oberley LW, Sun Y (1999) Transcriptional activation of the human glutathione peroxidase promoter by p53. J Biol Chem 274, 12061-12066. 
[34] Hussain SP, Amstad P, He P, Robles A, Lupold S, Kaneko I, Ichimiya M, Sengupta S, Mechanic L, Okamura S, Hofseth LJ, Moake M, Nagashima M, Forrester KS, Harris CC (2004) p53-induced up-regulation of MnSOD and GPx but not catalase increases oxidative stress and apoptosis. Cancer Res 64, 2350-2356.

[35] Yoon KA, Nakamura Y, Arakawa H (2004) Identification of ALDH4 as a p53-inducible gene and its protective role in cellular stresses. J Hum Genet 49, 134-140.

[36] Bensaad K, Tsuruta A, Selak MA, Vidal MN, Nakano K, Bartrons R, Gottlieb E, Vousden KH (2006) TIGAR, a p53inducible regulator of glycolysis and apoptosis. Cell 126, 107-120.

[37] Sablina AA, Budanov AV, Ilyinskaya GV, Agapova LS, Kravchenko JE, Chumakov PM (2005) The antioxidant function of the p53 tumor suppressor. Nat Med 11, 1306-1313.

[38] Vousden KH, Lu X (2002) Live or let die: the cell's response to p53. Nat Rev Cancer 2, 594-604.

[39] Polyak K, Xia Y, Zweier JL, Kinzler KW, Vogelstein B (1997) A model for p53-induced apoptosis. Nature 389, 300-305.

[40] Liu B, Chen Y, St Clair DK (2008) ROS and p53: a versatile partnership. Free Radic Biol Med 44, 1529-1535.

[41] Ferrante RJ, Browne SE, Shinobu LA, Bowling AC, Baik MJ, MacGarvey U, Kowall NW, Brown RH, Jr., Beal MF (1997) Evidence of increased oxidative damage in both sporadic and familial amyotrophic lateral sclerosis. J Neurochem $\mathbf{6 9}$, 2064-2074.

[42] Browne SE, Bowling AC, MacGarvey U, Baik MJ, Berger SC, Muqit MM, Bird ED, Beal MF (1997) Oxidative damage and metabolic dysfunction in Huntington's disease: selective vulnerability of the basal ganglia. Ann Neurol 41, 646-653.

[43] Schulz JB, Beal MF (1994) Mitochondrial dysfunction in movement disorders. Curr Opin Neurol 7, 333-339.

[44] Alam ZI, Jenner A, Daniel SE, Lees AJ, Cairns N, Marsden CD, Jenner P, Halliwell B (1997) Oxidative DNA damage in the parkinsonian brain: an apparent selective increase in 8hydroxyguanine levels in substantia nigra. J Neurochem $\mathbf{6 9}$, 1196-1203.

[45] Wang J, Xiong S, Xie C, Markesbery WR, Lovell MA (2005) Increased oxidative damage in nuclear and mitochondrial DNA in Alzheimer's disease. J Neurochem 93, 953-962.

[46] Mecocci P, MacGarvey U, Beal MF (1994) Oxidative damage to mitochondrial DNA is increased in Alzheimer's disease. Ann Neurol 36, 747-751.

[47] Rosen DR, Siddique T, Patterson D, Figlewicz DA, Sapp P, Hentati A, Donaldson D, Goto J, O'Regan JP, Deng HX, et al. (1993) Mutations in $\mathrm{Cu} / \mathrm{Zn}$ superoxide dismutase gene are associated with familial amyotrophic lateral sclerosis. Nature 362, 59-62.

[48] Zimmerman MC, Oberley LW, Flanagan SW (2007) Mutant SOD1-induced neuronal toxicity is mediated by increased mitochondrial superoxide levels. J Neurochem 102, 609-618.

[49] Boillee S, Vande Velde C, Cleveland DW (2006) ALS: a disease of motor neurons and their nonneuronal neighbors. Neuron 52, 39-59.

[50] Vijayvergiya C, Beal MF, Buck J, Manfredi G (2005) Mutant superoxide dismutase 1 forms aggregates in the brain mitochondrial matrix of amyotrophic lateral sclerosis mice. J Neurosci 25, 2463-2470.

[51] Ferri A, Cozzolino M, Crosio C, Nencini M, Casciati A, Gralla EB, Rotilio G, Valentine JS, Carri MT (2006) Familial ALS-superoxide dismutases associate with mitochondria and shift their redox potentials. Proc Natl Acad Sci U S A 103, 13860-13865.
[52] Gu M, Gash MT, Mann VM, Javoy-Agid F, Cooper JM, Schapira AH (1996) Mitochondrial defect in Huntington's disease caudate nucleus. Ann Neurol 39, 385-389.

[53] Bogdanov MB, Andreassen OA, Dedeoglu A, Ferrante RJ, Beal MF (2001) Increased oxidative damage to DNA in a transgenic mouse model of Huntington's disease. $\mathrm{J} \mathrm{Neu}$ rochem 79, 1246-1249.

[54] Perez-Severiano F, Santamaria A, Pedraza-Chaverri J, Medina-Campos ON, Rios C, Segovia J (2004) Increased formation of reactive oxygen species, but no changes in glutathione peroxidase activity, in striata of mice transgenic for the Huntington's disease mutation. Neurochem Res 29, 729733.

[55] Ferrante RJ, Andreassen OA, Dedeoglu A, Ferrante KL, Jenkins BG, Hersch SM, Beal MF (2002) Therapeutic effects of coenzyme Q10 and remacemide in transgenic mouse models of Huntington's disease. J Neurosci 22, 1592-1599.

[56] Bueler H (2010) Mitochondrial dynamics, cell death and the pathogenesis of Parkinson's disease. Apoptosis, in press.

[57] Liu W, Vives-Bauza C, Acin-Perez R, Yamamoto A, Tan Y, Li Y, Magrane J, Stavarache MA, Shaffer S, Chang S, Kaplitt MG, Huang XY, Beal MF, Manfredi G, Li C (2009) PINK1 defect causes mitochondrial dysfunction, proteasomal deficit and alpha-synuclein aggregation in cell culture models of Parkinson's disease. PLoS One 4, e4597.

[58] Palacino JJ, Sagi D, Goldberg MS, Krauss S, Motz C, Wacker M, Klose J, Shen J (2004) Mitochondrial dysfunction and oxidative damage in parkin-deficient mice. J Biol Chem $\mathbf{2 7 9}$, 18614-18622.

[59] Krebiehl G, Ruckerbauer S, Burbulla LF, Kieper N, Maurer B, Waak J, Wolburg H, Gizatullina Z, Gellerich FN, Woitalla D, Riess O, Kahle PJ, Proikas-Cezanne T, Kruger R (2010) Reduced basal autophagy and impaired mitochondrial dynamics due to loss of Parkinson's disease-associated protein DJ-1. PLoS One 5, e9367.

[60] Xiong H, Wang D, Chen L, Choo YS, Ma H, Tang C, Xia K, Jiang W, Ronai Z, Zhuang X, Zhang Z (2009) Parkin, PINK1, and DJ-1 form a ubiquitin E3 ligase complex promoting unfolded protein degradation. J Clin Invest 119, 650-660.

[61] Tanaka Y, Engelender S, Igarashi S, Rao RK, Wanner T, Tanzi RE, Sawa A, V LD, Dawson TM, Ross CA (2001) Inducible expression of mutant alpha-synuclein decreases proteasome activity and increases sensitivity to mitochondria-dependent apoptosis. Hum Mol Genet 10, 919-926.

[62] Devi L, Raghavendran V, Prabhu BM, Avadhani NG, Anandatheerthavarada HK (2008) Mitochondrial import and accumulation of alpha-synuclein impair complex I in human dopaminergic neuronal cultures and Parkinson disease brain. J Biol Chem 283, 9089-9100.

[63] Martin LJ, Pan Y, Price AC, Sterling W, Copeland NG, Jenkins NA, Price DL, Lee MK (2006) Parkinson's disease alphasynuclein transgenic mice develop neuronal mitochondrial degeneration and cell death. J Neurosci 26, 41-50.

[64] Manczak M, Anekonda TS, Henson E, Park BS, Quinn J, Reddy PH (2006) Mitochondria are a direct site of A beta accumulation in Alzheimer's disease neurons: implications for free radical generation and oxidative damage in disease progression. Hum Mol Genet 15, 1437-1449.

[65] Caspersen C, Wang N, Yao J, Sosunov A, Chen X, Lustbader JW, Xu HW, Stern D, McKhann G, Yan SD (2005) Mitochondrial Abeta: a potential focal point for neuronal metabolic dysfunction in Alzheimer's disease. FASEB J 19, 2040-2041.

[66] Querfurth HW, LaFerla FM (2010) Alzheimer's disease. $N$ Engl J Med 362, 329-344. 
[67] Casley CS, Canevari L, Land JM, Clark JB, Sharpe MA (2002) Beta-amyloid inhibits integrated mitochondrial respiration and key enzyme activities. $J$ Neurochem 80, 91-100.

[68] Wang X, Su B, Lee HG, Li X, Perry G, Smith MA, Zhu X (2009) Impaired balance of mitochondrial fission and fusion in Alzheimer's disease. J Neurosci 29, 9090-9103.

[69] Yu T, Robotham JL, Yoon Y (2006) Increased production of reactive oxygen species in hyperglycemic conditions requires dynamic change of mitochondrial morphology. Proc Natl Acad Sci U S A 103, 2653-2658.

[70] Wang X, Su B, Siedlak SL, Moreira PI, Fujioka H, Wang Y, Casadesus G, Zhu X (2008) Amyloid-beta overproduction causes abnormal mitochondrial dynamics via differential modulation of mitochondrial fission/fusion proteins. Proc Natl Acad Sci U S A 105, 19318-19323.

[71] Karuppagounder SS, Xu H, Shi Q, Chen LH, Pedrini S, Pechman D, Baker H, Beal MF, Gandy SE, Gibson GE (2009) Thiamine deficiency induces oxidative stress and exacerbates the plaque pathology in Alzheimer's mouse model. Neurobiol Aging 30, 1587-1600.

[72] Esteves AR, Arduino DM, Swerdlow RH, Oliveira CR, Cardoso SM (2009) Oxidative stress involvement in alphasynuclein oligomerization in Parkinson's disease cybrids. Antioxid Redox Signal 11, 439-448.

[73] Batelli S, Albani D, Rametta R, Polito L, Prato F, Pesaresi M, Negro A, Forloni G (2008) DJ-1 modulates alpha-synuclein aggregation state in a cellular model of oxidative stress: relevance for Parkinson's disease and involvement of HSP70. PLoS One 3, e1884.

[74] Sheehan JP, Swerdlow RH, Miller SW, Davis RE, Parks JK, Parker WD, Tuttle JB (1997) Calcium homeostasis and reactive oxygen species production in cells transformed by mitochondria from individuals with sporadic Alzheimer's disease. J Neurosci 17, 4612-4622.

[75] LaFerla FM (2002) Calcium dyshomeostasis and intracellular signalling in Alzheimer's disease. Nat Rev Neurosci 3, 862-872.

[76] Isaacs AM, Senn DB, Yuan M, Shine JP, Yankner BA (2006) Acceleration of amyloid beta-peptide aggregation by physiological concentrations of calcium. J Biol Chem 281, 2791627923.

[77] Alberdi E, Sanchez-Gomez MV, Cavaliere F, Perez-Samartin A, Zugaza JL, Trullas R, Domercq M, Matute C (2010) Amyloid beta oligomers induce $\mathrm{Ca}(2+)$ dysregulation and neuronal death through activation of ionotropic glutamate receptors. Cell Calcium 47, 264-272.

[78] He C, Klionsky DJ (2009) Regulation mechanisms and signaling pathways of autophagy. Annu Rev Genet 43, 67-93.

[79] Hara T, Nakamura K, Matsui M, Yamamoto A, Nakahara Y, Suzuki-Migishima R, Yokoyama M, Mishima K, Saito I, Okano H, Mizushima N (2006) Suppression of basal autophagy in neural cells causes neurodegenerative disease in mice. Nature 441, 885-889.

[80] Komatsu M, Waguri S, Chiba T, Murata S, Iwata J, Tanida I, Ueno T, Koike M, Uchiyama Y, Kominami E, Tanaka K (2006) Loss of autophagy in the central nervous system causes neurodegeneration in mice. Nature 441, 880-884.

[81] Geisler S, Holmstrom KM, Skujat D, Fiesel FC, Rothfuss OC, Kahle PJ, Springer W (2010) PINK1/Parkin-mediated mitophagy is dependent on VDAC1 and p62/SQSTM1. Nat Cell Biol 12, 119-131.

[82] Narendra D, Tanaka A, Suen DF, Youle RJ (2008) Parkin is recruited selectively to impaired mitochondria and promotes their autophagy. J Cell Biol 183, 795-803.
[83] Vives-Bauza C, Zhou C, Huang Y, Cui M, de Vries RL, Kim J, May J, Tocilescu MA, Liu W, Ko HS, Magrane J, Moore DJ, Dawson VL, Grailhe R, Dawson TM, Li C, Tieu K, Przedborski S (2010) PINK1-dependent recruitment of Parkin to mitochondria in mitophagy. Proc Natl Acad Sci U $S$ A 107, 378-383.

[84] Narendra DP, Jin SM, Tanaka A, Suen DF, Gautier CA, Shen J, Cookson MR, Youle RJ (2010) PINK1 is selectively stabilized on impaired mitochondria to activate Parkin. PLoS Biol 8, e1000298.

[85] Festjens N, Vanden Berghe T, Vandenabeele P (2006) Necrosis, a well-orchestrated form of cell demise: signalling cascades, important mediators and concomitant immune response. Biochim Biophys Acta 1757, 1371-1387.

[86] Chipuk JE, Moldoveanu T, Llambi F, Parsons MJ, Green DR (2010) The BCL-2 Family Reunion. Mol Cell 37, 299-310.

[87] Youle RJ, Strasser A (2008) The BCL-2 protein family: opposing activities that mediate cell death. Nat Rev Mol Cell Biol 9, 47-59.

[88] Cho BB, Toledo-Pereyra LH (2008) Caspase-independent programmed cell death following ischemic stroke. J Invest Surg 21, 141-147.

[89] Mathai JP, Germain M, Marcellus RC, Shore GC (2002) Induction and endoplasmic reticulum location of BIK/NBK in response to apoptotic signaling by $\mathrm{E} 1 \mathrm{~A}$ and $\mathrm{p} 53$. Oncogene 21, 2534-2544.

[90] Hubner A, Barrett T, Flavell RA, Davis RJ (2008) Multisite phosphorylation regulates Bim stability and apoptotic activity. Mol Cell 30, 415-425.

[91] Morel C, Carlson SM, White FM, Davis RJ (2009) Mcl-1 integrates the opposing actions of signaling pathways that mediate survival and apoptosis. Mol Cell Biol 29, 3845-3852.

[92] Maiuri MC, Le Toumelin G, Criollo A, Rain JC, Gautier F, Juin P, Tasdemir E, Pierron G, Troulinaki K, Tavernarakis N, Hickman JA, Geneste O, Kroemer G (2007) Functional and physical interaction between $\mathrm{Bcl}-\mathrm{X}(\mathrm{L})$ and a $\mathrm{BH} 3$-like domain in Beclin-1. EMBO J 26, 2527-2539.

[93] Pattingre S, Tassa A, Qu X, Garuti R, Liang XH, Mizushima N, Packer M, Schneider MD, Levine B (2005) Bcl-2 antiapoptotic proteins inhibit Beclin 1-dependent autophagy. Cell 122, 927-939.

[94] Wei Y, Pattingre S, Sinha S, Bassik M, Levine B (2008) JNK1-mediated phosphorylation of Bcl-2 regulates starvation-induced autophagy. Mol Cell 30, 678-688.

[95] Puissant A, Robert G, Fenouille N, Luciano F, Cassuto JP, Raynaud S, Auberger P (2010) Resveratrol promotes autophagic cell death in chronic myelogenous leukemia cells via JNK-mediated p62/SQSTM1 expression and AMPK activation. Cancer Res 70, 1042-1052.

[96] Scarlatti F, Granata R, Meijer AJ, Codogno P (2009) Does autophagy have a license to kill mammalian cells? Cell Death Differ 16, 12-20.

[97] Smith RA, Adlam VJ, Blaikie FH, Manas AR, Porteous CM, James AM, Ross MF, Logan A, Cocheme HM, Trnka J, Prime TA, Abakumova I, Jones BA, Filipovska A, Murphy MP (2008) Mitochondria-targeted antioxidants in the treatment of disease. Ann N Y Acad Sci 1147, 105-111.

[98] Jauslin ML, Meier T, Smith RA, Murphy MP (2003) Mitochondria-targeted antioxidants protect Friedreich Ataxia fibroblasts from endogenous oxidative stress more effectively than untargeted antioxidants. FASEB J 17, 1972-1974.

[99] Graham D, Huynh NN, Hamilton CA, Beattie E, Smith RA, Cocheme HM, Murphy MP, Dominiczak AF (2009) Mitochondria-targeted antioxidant MitoQ10 improves en- 
dothelial function and attenuates cardiac hypertrophy. $\mathrm{Hy}$ pertension 54, 322-328.

[100] Antonenko YN, Roginsky VA, Pashkovskaya AA, Rokitskaya TI, Kotova EA, Zaspa AA, Chernyak BV, Skulachev VP (2008) Protective effects of mitochondria-targeted antioxidant $\mathrm{SkQ}$ in aqueous and lipid membrane environments. J Membr Biol 222, 141-149.

[101] Skulachev VP, Anisimov VN, Antonenko YN, Bakeeva LE, Chernyak BV, Erichev VP, Filenko OF, Kalinina NI, Kapelko VI, Kolosova NG, Kopnin BP, Korshunova GA, Lichinitser MR, Obukhova LA, Pasyukova EG, Pisarenko OI, Roginsky VA, Ruuge EK, Senin, II, Severina, II, Skulachev MV, Spivak IM, Tashlitsky VN, Tkachuk VA, Vyssokikh MY, Yaguzhinsky LS, Zorov DB (2009) An attempt to prevent senescence: a mitochondrial approach. Biochim Biophys Acta 1787, 437 461.

[102] Zhao K, Zhao GM, Wu D, Soong Y, Birk AV, Schiller PW, Szeto HH (2004) Cell-permeable peptide antioxidants targeted to inner mitochondrial membrane inhibit mitochondrial swelling, oxidative cell death, and reperfusion injury. J Biol
Chem 279, 34682-34690.

[103] Zhao K, Luo G, Giannelli S, Szeto HH (2005) Mitochondriatargeted peptide prevents mitochondrial depolarization and apoptosis induced by tert-butyl hydroperoxide in neuronal cell lines. Biochem Pharmacol 70, 1796-1806.

[104] Thomas DA, Stauffer C, Zhao K, Yang H, Sharma VK, Szeto HH, Suthanthiran M (2007) Mitochondrial targeting with antioxidant peptide SS-31 prevents mitochondrial depolarization, reduces islet cell apoptosis, increases islet cell yield, and improves posttransplantation function. J Am Soc Nephrol 18, 213-222.

[105] Petri S, Kiaei M, Damiano M, Hiller A, Wille E, Manfredi G, Calingasan NY, Szeto HH, Beal MF (2006) Cell-permeable peptide antioxidants as a novel therapeutic approach in a mouse model of amyotrophic lateral sclerosis. J Neurochem 98, $1141-1148$.

[106] Yang L, Zhao K, Calingasan NY, Luo G, Szeto HH, Beal MF (2009) Mitochondria targeted peptides protect against 1-methyl-4-phenyl-1,2,3,6-tetrahydropyridine neurotoxicity. Antioxid Redox Signal 11, 2095-2104. 